\title{
Field dissipation of pendimethalin and alachlor in sandy clay loam soil and its terminal residues in sunflower (Helianthus annus $L$.)
}

\section{P. Janaki*, C. Chinnusamy, N. Sakthivel and C. Nithya}

All India Coordinated Research Project on Weed Control, Department of Agronomy, Tamil Nadu Agricultural University, Coimbatore- 641003, INDIA

*Corresponding author. E-mail: janakibalamurugan@rediffmail.com

Received: March 12,2015; Revised received: July 20, 2015; Accepted: September 8, 2015

\begin{abstract}
Field experiments were conducted with sunflower as a test crop during 2010-11 to study the dissipation kinetics and the persistence of pendimethalin and alachlor in sandy clay loam soil and its terminal residues in sunflower. Herbicides were applied at recommended and double the recommended dose along with control and the treatments were replicated thrice in randomized block design. The soil and plant samples collected at periodical intervals for herbicides residue determination using GC equipped with ECD detector. Results shows that the degradation of both the herbicides in soil was faster at higher dose of application than at the lower dose and the concentration decreased with the advancement in crop growth. While pendimethalin persisted in soil for $60-90$ days, the alachlor persisted in soil for 30 - 45 days depending on the quantity of application. Degradation of both the herbicides in soil followed first order kinetics with the mean half life of 14.6 and 9.8 days respectively for pendimethalin and alachlor. Residues of these herbicides were below $0.001 \mathrm{mg} / \mathrm{kg}$ at the time of harvest in soil, sunflower seeds and stalks showed that these herbicides a can be safely used for the control of weeds in sunflower cultivation.
\end{abstract}

Keywords: Alachlor, Dissipation, Pendimethalin, Persistence, Sunflower

\section{INTRODUCTION}

Sunflower (Helianthus annus L.) is one of the important oil seeds crop in India and is the preferred edible oil by the consumers' world over and in India too due to health appeal. Sunflower is also a crop of choice for farmers due to its wider adaptability, high yield potential, shorter duration and profitability (Anonymous, 2010). Sunflower has a medium tolerance for weeds because of their lower compe-tition ability. Weed competition is mani-fested by a decrease of sunflower biomass and yield loss and depends on weed density, time of competition and duration, weed spectrum and other factors (Carranza et al., 1995). The yield reduction due to weeds in sunflower is estimated to be as high as 81 per cent (Jaykumar et al., 1988). Due to acute labour shortage and relatively tender nature of the sunflower, adopting the hand weeding or mechanical weeding, circumvented the chemical weed control as the only available option. However the herbicides available for chemical weed control are mostly pre emergence and also are relatively high in selectivity to sunflower. This is because most herbicides were primarily developed for weed control in economically more important crops (Gressel, 2002), and intensive precipitation after application of these herbicides can cause high phytotoxicity to sunflower, especially in sandy soils (Jursik et al., 2011). Hence it is essential to study the field dissipation of pendimethalin and alachlor which are frequently used in Tamil Nadu to have good weed control and achieve higher yield of sunflower.

Alachlor [2-chloro-2-, 6-diethyl-N-(methoximethyl) acetanilide] is a chloro-acetamide herbicide widely used to control grass weeds in corn, soyabean, sugarcane, and other crops. The primary factors that affect the degradation of acetanilide herbicides in soils are microbial activity and organic matter and clay contents (Weber and Peter, 1982). The dissipation of alachlor in soil was found to follow the first-order kinetics and the half-life in soil varied from 2.6 to 7.8 days (Ramesh and Maheswari, 2004; Shaner, 2012) under different cropped soils. In soil, alachlor degradation was found to increase with time and also increases with increase in soil $\mathrm{pH}$ (Sethi and Chopra, 1975). Janaki et al. (2012a) reported that the sorption of alachlor in soil is affected by the organic matter and clay content and was high in soil with high organic matter. Pendimethalin is grouped under dinitroaniline family with the field half lives of 60 and 44 days respectively (Vencill, 2002). Tsiropoulos and Lolas (2003) reported that the half life of pendimethalin varied from 43 and 62 days in the soil grown with cotton under drip and normal irrigated conditions. Degradation of pendimethalin was faster under anaerobic condition than aerobic condition and varies with soil moisture and temperature (Vencill, 2002). 
Janaki et al. (2012b) found that the degradation of both alachlor and pendimethalin in soil depends on the intrinsic properties of the herbicides and soil properties with the half life of alachlor and pendimethalin ranged from $4.4-5.1$ and 13.2 - 16.0 days respectively in sandy clay loam soils. In India, most literatures on these herbicides has been limited to laboratory dissipation studies and other field crops and other oilseeds (Janaki et al., 2009; 2012b; Sondhia, 2014) and only under north Indian subtropical humid ecosystem on wheat (Kulshrestha and Yaduraju, 1987), maize-wheat cropping system (Kulshrestha et al., 2000; Sondhia, 2014) and few literatures on microbial degradation (Singh and Kulshretha, 1991). Similar is the case with respect to alachlor behaviuor in soil (Janaki et al., 2009; Sondhia, 2014). In view of these facts, and the persistence of herbicide is correlated not only with climatic conditions, but also with management practices and soil physico-chemistry (Sondhia, 2013; Janaki et al., 2015), the behaviour of herbicides in subtropical semi arid agro climatic conditions need to be examined. Hence this study was carried out to scrutinize the field dissipation behavior of pendimethalin and alachlor in sandy clay loam and its terminal residues in sunflower crop.

\section{MATERIALS AND METHODS}

Field experiments were carried out at Eastern Block Farm of Tamil Nadu Agricultural University, Coimbatore, Tamil Nadu, India during Rabi season 2010-2011 in randomized block design with three replications. Field was prepared to fine tilth as needed for each crop and all agronomic and cultural practices were followed as recommended for each crop. Each treatment plot was of $5 \times 4 \mathrm{~m}^{2}$ in dimension and all four sides of the plots were protected by soil boundaries raised to a level of $40 \mathrm{~cm}$ height and $30 \mathrm{~cm}$ width. One meter distance was maintained between plots. Both the herbicides were applied as pre emergence at two levels (x-Recommended dose; $2 \mathrm{x}$ - Double the recommended dose) along with the Control (no herbicide application). Herbicides were sprayed using Knapsack sprayer with the spray volume of 500 lit of water ha $^{-1}$. Water alone was sprayed in control treatment to maintain the uniformity. Experimental fields soil were sandy clay loam (sand $32 \%$, clay $29 \%$ and silt $24 \%$ per cent) in texture and has the $\mathrm{pH}-7.0, \mathrm{EC}-0.08$ $\mathrm{dSm}^{-1}$, organic carbon $-0.36 \%$, low in available nitrogen, medium in available phosphorus and high in available potassium.

Soil samples were collected at different intervals viz., $0,(2 \mathrm{hrs}), 5,10,20,30,45,60,90$ days after herbicide application and also at the time of crop harvest. About $500 \mathrm{~kg}$ of soil sample was collected randomly from each plot using a soil auger up to a depth of $15 \mathrm{~cm}$ from the surface. Pebbles and other unwanted materials were removed, the soil sample was homogenized thoroughly and about $250 \mathrm{~g}$ was sub sampled for the analysis of herbicide residues. Collected samples were stored at $-10{ }^{0} \mathrm{C}$, processed and analyzed within seven days.

While alachlor was extracted from soil samples using acetonitrile, pendimethalin was extracted with methanol and the extracts were filtered and evaporated at $60^{\circ} \mathrm{C}$ to about $10 \mathrm{ml}$. The cleanup of all herbicide residues was done using anhydrous sodium sulphate / $\mathrm{NaCl}$ and florisil. Dried residues were re-dissolved in known volume of acetone / hexane to inject in to gas chromatograph (Janaki et al., 2012b). Residues of all herbicides were determined using gas chromatograph equipped with electron capture detector (ECD). Separation of the compound was achieved using mega bore capillary column of $30 \mathrm{~m} \times 0.53 \mathrm{~mm}$, ID-BP1 0.5 $\mu \mathrm{m}$ following the instrumental conditions as suggested by Janaki et al. (2012b).

Different known concentrations of both herbicides (2.0, 1.0, 0.5, 0.1, 0.01 and $0.001 \mathrm{mg} \mathrm{kg}^{-1}$ ) studied were prepared in acetone/ hexane by diluting the stock solution. $0.5 \mu \mathrm{l}$ of standard solution was injected and the peak area measured. Validation of the method was performed in terms of recovery studies before analysis of unknown sample. The recovery study was conducted for all herbicides in soil. The average recovery and detection limits of all herbicides are shown in table 1. Degradation of herbicide was described using first order kinetics as given by Timme et al. (1986).

\section{RESULTS AND DISCUSSION}

Efficiency of the extraction methods of both the herbicides were validated through recovery studies and found that the overall recovery of both the herbicides were above 80 per cent and confirms the suitability of the extraction methods for the determination of pendimethalin and alachlor residues in soil and sunflower stalk and seeds. The average recoveries for each herbicide varied from 80-84 and 79-82 percent for pendimethalin and alachlor respectively (Table 1) across different matrices.

The initial concentration of both the herbicides in soil ( $2 \mathrm{hrs}$ after their application) was varied with the quantity of application (Table 2). Generally higher rate of deposition was recorded under double the recommended rate of application and varied with the herbicides (Kulshrestha and Yaduraju, 1987). Initial deposition of different herbicides in soil was in the order of pendimethalin $>$ alachlor and could be attributed to the rate of application (Janaki et al., 2012b). Further the difference in initial deposition could be attributed to the physical and chemical properties of the herbicides such as organic-carbon and mineral-surface sorption coefficients, aqueous solubility, soil dissipation half-life etc., and environment factors such as application rate, herbicide persistence and mobility, rainfall, topography, and climate (Lin et al., 1999, Shaner, 2012). 
Table 1. Gas chromatographic conditions and recovery of herbicides from soil.

\begin{tabular}{rcccccc}
\hline $\begin{array}{c}\text { Herbicide } \\
\text { molecules }\end{array}$ & $\begin{array}{c}\text { Temperature } \\
\text { conditions }\left(\mathbf{(}^{\mathbf{C})}\right. \\
\text { Oven / Injection / } \\
\text { Detector }\end{array}$ & $\begin{array}{c}\text { Retention } \\
\text { time } \\
\text { (minutes) }\end{array}$ & $\begin{array}{c}\text { Limit of } \\
\text { detection } \\
(\boldsymbol{\mu g} / \mathbf{g})\end{array}$ & $\begin{array}{c}\text { Average } \\
\text { Recovery } \\
\text { in soil (\%) }\end{array}$ & $\begin{array}{c}\text { Average } \\
\text { Recovery in } \\
\text { sunflower } \\
\text { seeds (\%) }\end{array}$ & $\begin{array}{c}\text { Average } \\
\text { Recovery in } \\
\text { sunflower } \\
\text { stalks (\%) }\end{array}$ \\
\hline Pendimethalin & $185-220 / 240 / 260$ & 3.47 & 0.001 & 84 & 82 & 80 \\
Alachlor & $240 / 220 / 260$ & 2.49 & 0.001 & 82 & 79 & 81 \\
\hline
\end{tabular}

Table 2. Persistence $(\mathrm{mg} / \mathrm{kg})$ of herbicides in soil under sunflower.

\begin{tabular}{ccccc}
\hline $\begin{array}{c}\text { Days after herbi- } \\
\text { cide application }\end{array}$ & \multicolumn{2}{c}{ Pendimethalin } & \multicolumn{2}{c}{ Alachlor } \\
\cline { 2 - 5 } $\mathbf{1 ~ \mathbf { ~ g } / \mathbf { h a }}$ & $\mathbf{2} \mathbf{~ h a}$ & $\mathbf{0 . 5} \mathbf{~ k g} / \mathbf{h a}$ & $\mathbf{1 . 0} \mathbf{~ k g} / \mathbf{h a}$ \\
\hline 0 & 0.924 & 2.200 & 0.397 & 0.876 \\
5 & 0.718 & 1.870 & 0.279 & 0.741 \\
10 & 0.572 & 1.541 & 0.184 & 0.597 \\
20 & 0.328 & 0.866 & 0.074 & 0.323 \\
30 & 0.208 & 0.568 & 0.023 & 0.161 \\
45 & 0.126 & 0.282 & BDL & 0.081 \\
60 & 0.078 & 0.145 & BDL & BDL \\
90 & BDL & 0.042 & BDL & BDL \\
At harvest & BDL & BDL & BDL & BDL \\
\hline
\end{tabular}

Table 3. Optimized first order field dissipation curves of herbicides under sunflower cropping as influenced by quantity of application.

\begin{tabular}{lccc}
\hline \multicolumn{1}{c}{ Herbicides* } & DT $_{\mathbf{5 0}}$ & Predicted equation & Goodness of fit \\
\hline Pendimethalin @ $1 \mathrm{~kg} / \mathrm{ha}$ & 13.9 & $\mathrm{y}=-0.009 \mathrm{x}+0.677$ & $\mathrm{R}^{2}=0.772$ \\
Pendimethalin @ $2 \mathrm{~kg} / \mathrm{ha}$ & 15.4 & $\mathrm{y}=-0.023 \mathrm{x}+1.715$ & $\mathrm{R}^{2}=0.790$ \\
Alachlor @ $0.5 \mathrm{~kg} / \mathrm{ha}$ & 7.3 & $\mathrm{y}=-0.006 \mathrm{x}+0.285$ & $\mathrm{R}^{2}=0.753$ \\
Alachlor @ $1.0 \mathrm{~kg} / \mathrm{ha}$ & 12.3 & $\mathrm{y}=-0.014 \mathrm{x}+0.753$ & $\mathrm{R}^{2}=0.891$ \\
\hline
\end{tabular}

* $\mathrm{x}$ - Recommended dose; $2 \mathrm{x}$ - double the recommended dose

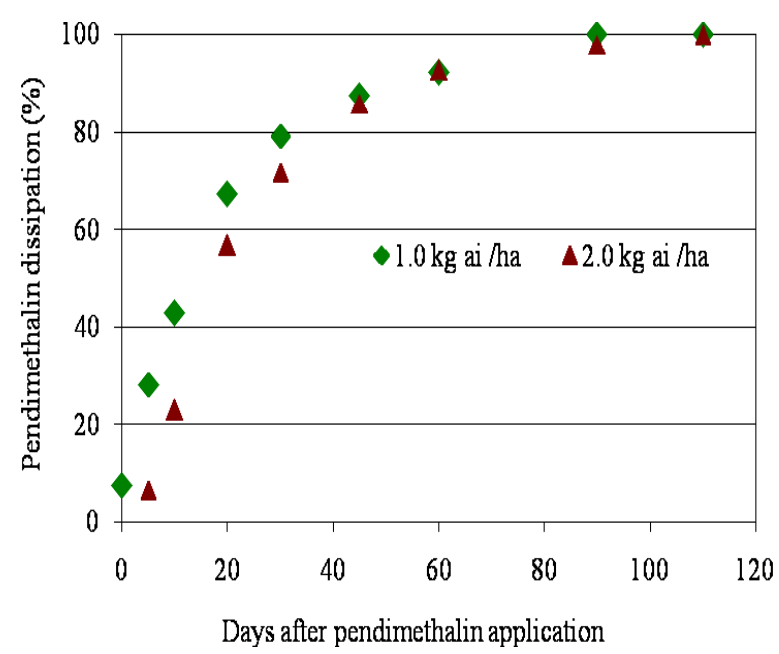

Fig. 1. Field dissipation of pendimethalin in sandy clay loam soil under sunflower.

Persistence characteristics of both the herbicides are shown in table 2 and residues of them decreased consistently with the advancement of time. Application of pendimethalin at $1 \mathrm{~kg} \mathrm{ha}^{-1}$ persisted in soil up to 60 days while up to 90 days at $2 \mathrm{~kg} \mathrm{ha}^{-1}$ application rate (Table 2). This is in line with the findings of Arora and Tomar (2008) and Janaki et al. (2009) that the application of pendimethalin at $1.0 \mathrm{~kg} \mathrm{ha}^{-1}$ to different rabi crops

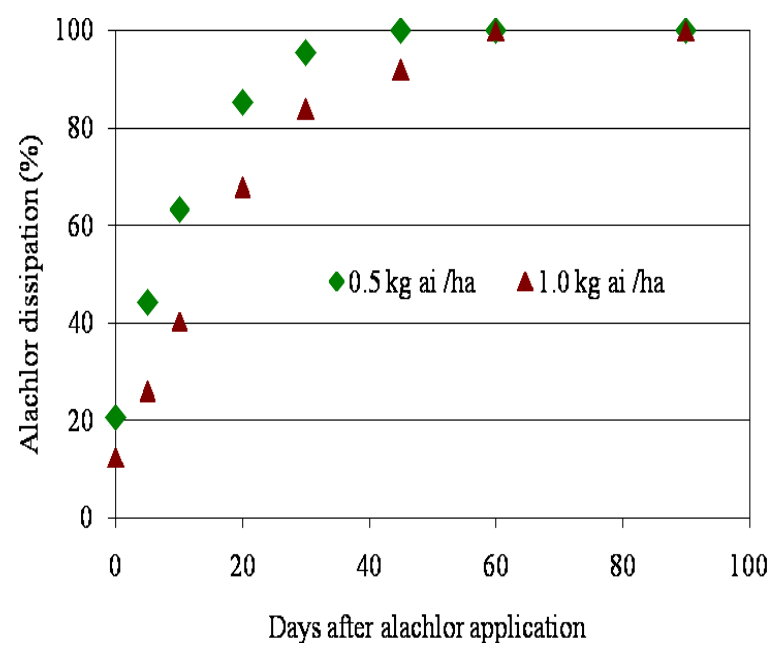

Fig. 2. Field dissipation of alachlor in sandy clay loam soil under sunflower.

persisted in soil up to 75 days after sowing and afterwards degraded completely leaving no toxic residue in post harvest soil. The residues of alachlor persisted in soil up to 30 and 45 days after application (Table 2) under 0.5 and $1.0 \mathrm{~kg} /$ ha applied plots respectively. Thereafter the residue concentration went down below detectable level. The dissipation of herbicides in soil followed first order kinetics and the corresponding 
data fitting first order kinetics are given in table 3, Figs. 1 and 2. The correlation coefficient $\left(r^{2}\right)$ derived from the regression lines lies between 0.753 and 0.891 and the best fit was observed for alachlor at the application of double the recommended dose. Pendimethalin dissipation followed biphasic pattern of degradation i.e. initial faster dissipation up to 20 days thereafter their dissipation becomes slow. This could be attributed to an equilibrium that was reached with this herbicide where soil adsorption had occurred and then desorption of the parent molecule over time (Patakioutas and Albanis, 2002). Similar biphasic pattern of pendimethalin degradation in soil under sunflower cropped field ie., initial rapid loss between 3 to $5 \mathrm{~d}$ after application and then a slower rate was reported by Shaner (2012) in Colorado. Faster dissipation of pendimethalin at later stages could be ascribed to the enhanced microbial degradation due to increased population after an initial lag phase (Singh and Kulashretha, (1991).

Half life of the herbicides increased with the increase in its applied concentration. The mean half life of initial concentration of herbicides studied in sandy clay loam was 14.6 and 9.8 days for pendimethalin and alachlor respectively (Table 2). Similar half-life 23-30 days for pendimethalin under field conditions was reported by Lee et al. (2000) and also found that its half life was not affected by the dose and rainfall treatment. Higher half life of pendimethalin when compared to alachlor could be attributed to the bounding of pendimethalin to soil organic matter and slow loss from soil rich in clay or organic matter (Kulshrestha and Yaduraju, 1987) besides it's immobility in soil (Vencill, 2002). Further the degradation of these herbicides in soil initially depends on the intrinsic properties of the herbicides, secondly on the soil properties and climatic conditions (Janaki et al., 2012b; Shohba, 2014). Alachlor dissipated at a faster rate than pendimethalin which might be due to the faster microbial degradation of this herbicide in soil. It was found that the residues of these herbicides in the seeds and stalks of sunflower were below the detectable limit of $0.001 \mathrm{mg} / \mathrm{kg}$.

The maximum residue limits (MRLs) of alachlor and pendimethalin on sunflower crop have not been established yet by EPA/FSSAI, whereas the MRL was set as $0.05 \mathrm{mg} / \mathrm{kg}$ on oilseeds by EFSA (2014 and 2015) and for soybean by FSSAI (2011). Under the present experimental conditions, the residues in crop produce at harvest were below the MRL's set by both FSSAI and EFSA for some oilseeds; consequently, the alachlor and pendimethalin at the present recommended application rates could be considered safe to food and environment.

\section{Conclusion}

It was concluded that the initial deposition of herbicides was influenced by the quantity of application and showed that the persistence decreased with the progression of crop growth and with the mean half life of 14.6 and 9.8 days respectively for pendimethalin and alachlor. However, the pendimethalin degradation followed biphasic pattern of degradation and persistence of both the herbicides followed first order reaction kinetics. These herbicides may be safely applied for the weed control in sunflower at recommended level, since the residues in soil, seeds and stalk were well below the MRL's besides establishing its safety to the succeeding crops.

\section{ACKNOWLEDGEMENTS}

Authors kindly acknowledge the Directorate of Weed Research, Indian Council of Agricultural Research (ICAR), Jabalpur and Tamil Nadu Agricultural University, Coimbatore for funding to conduct this study through All India Coordinated Research Project on Weed Control.

\section{REFERENCES}

Annonymous (2010). http://www.advantaindia.com/ index.php?pgidee=sunflower. retrived during February, 2015.

Arora, A. and Tomar, S.S. (2008). Persistence of pendimethalin in soil applied to different crops. Agric. Sci. Digest, 28(4): 295-297.

Carranza, P., Saavedra, M. and Garcia-Torres, L. (1995). Competition between Ridolfia segetum and sunflower. Weed Research, 35: 369-375.

EFSA (European Food Safety Authority). (2014). Reasoned opinion on the modification of the existing MRLs for pendimethalin in various crops1. EFSA Journal, 12 (4):3620

EFSA (European Food Safety Authority). (2015). The 2013 European Union report on pesticide residues in food. EFSA Journal, 13(3):4038

FSSAI (Food Safety and Standards Authority of India). 2011. Food safety and standards (contaminants, toxins and residues) regulations, 2011. http://www.fssai.gov.in

Gressel, J.B. (2002). Molecular Biology of Weed Control. Taylor \& Francis, London.

Janaki, P., Meena, S. and Chinnusamy, C. (2009). Persistence and Degradation of Herbicides in Rice, Maize and Soybean Grown Vertisols of Tamil Nadu, Southern India. In: Proceedings of the 2nd International Conference on "Novel and Sustainable Weed Management in Arid and Semi-Arid agro Ecosystem" held between $7^{\text {th }}$ September and $10^{\text {th }}$ September, 2009 at Santorini, Athens, Greece. Retrieved in http:// slideplayer.com/slide/3843757/

Janaki, P., Chinnusamy, C. and Nalini, K. (2012a). Adsorption and desorption behaviour of alachlor in dfferent soils of Tamil Nadu. Journal of the India Society of Soil Sci., 60 (3): $230-232$.

Janaki, P., Meena, S. and Chinnusamy, C. (2012b). Field dissipation of herbicides under different crops in Tamil Nadu. Madras Agricultural J., 99 (10-12):794-798.

Janaki, P., Meena, S. and Chinnusamy, C. (2015). Dynamics of metolachlor in sandy clay loam soil and its residues in maize and soybean. Trends in Biosciences 8(1): 131-137.

Jaykumar, R., Premsekar, M; Kempuchetty, N. and Subramaniam, S. (1988). Effect of integrated weed management on 
yield and quality of sunflower. Madras Agric. J., 75: 304.

Jursik, M., Andr, J; Holec, J. and Soukup, J. (2011). Efficacy and selectivity of post-emergent applicationof flumioxazin and oxyfluorfen in sunflower. Plant Soil Environ., 57 (11): 532-539

Kulshrestha, G. and Yaduraju, N.T. (1987). Persistence of pendimethalin in soil following pre-emergence application to wheat. Indian J. Agron., 32: $271-275$

Kulshrestha, G; Singh, S.B; Lal, S.P. and Yaduraju, N.T. 2000. Effect of long-term field application of pendimethalin: enhanced degradation in soil. Pest Management Science. 56(2): 202-206.

Lee, D.R; Miller, D.K; Vidrine, P.R. and Kell, S.T. (2000). Evaluation of Suprend for weed control in cotton. In: Proc. Southern Weed Sci. Soc., Houston, Tx. 27-29 Jan. 2003. Southern Weed Sci. Soc., Champaign, IL. p. 286.

Lin, Y.j; Karuppiah, M; Shaw, A. and Gupta, G. (1999). Effect of simulated sunlight on atrazine and metolachlor toxicity of surface waters. Ecotoxicology and Environmental Safety, 43: 35-37.

Patakioutas, G. and Albanis, T.A. (2002). Adsorption-desorption studies of alachlor, metolachlor, EPTC, chlorothalonil and pirimiphos-methyl in contrasting soils. Pest Management Science, 58:352-362.

Ramesh, A. and Maheswari, S.T. (2004). Dissipation of alachlor in cotton plant, soil and water and its bioaccumulation in fish. Chemosphere, 54: 647-652

Sethi, R.K. and Chopra, S.L. (1975). Adsorption, degradation and leaching of alachlor in some soils. J Indian Soc Soil Sci., 23: 184-194.

Shaner, D.L. 2012. Field Dissipation of Sulfentrazone and Pendimethalin in Colorado. Weed Technology, 26 (4):633-637. 2012.

Sondhia S. (2013). Dissipation of pendimethalin in the soil of field pea (Pisum sativum L.) and detection of terminal residues in plants. Journal of Environmental Science and Health Part B 48(12): 104-1048.

Sondhia, S. (2014). Herbicides residues in soil, water, plants and non-targeted organisms and human health implications: an Indian perspective. Indian Journal of Weed Science 46 (1): 66-85, 2014

Singh, S.B. and Kulshretha, G. (1991). Microbial degradation of pendimethalin. J. Environ. Sci. Health B. 26: $309-321$.

Timme, G., Frehse, H. and Laska, V. (1986). Statistical interpretation and graphic representation of the degradation behavior of pesticide residues. II. Pflanxenschutz -Nachrichten Bayer, 39: 189-203.

Tsiropoulos, N.G. and Lolas, P.C. (2003). Persistence of pendimethalin in cotton fields under sprinkler or drip irrigation in central Greece. International Journal of Environmental and Analytical Chemistry, 84:199-205

Weber, J.B. and Peter, J. (1982). Adsorption, bio-activity, and evaluation of soil tests for alachlor, acetochlor, and metolachlor. Weed Science, 30: 14-20.

Vencill, W.K. (2002). Herbicide Hand book. $8^{\text {th }}$ edition, Weed Science Society of America, Lawrence, KS, U.S.A. pp 1-440. 